\title{
HISTAMINE CONTENT OF THE RAT UTERUS CONTAINING AN IUCD
}

\author{
EARL PARR \\ Rockefeller University, New York City, New York
}

(Received 21st March 1967)

\begin{abstract}
Summary. Measurements of histamine in control and IUCD-containing uterine horns of the rat in di-oestrus and $\mathrm{L}_{4}$ of pregnancy showed that device-containing horns had a higher concentration and content per horn than did control horns at both times. In control horns, the histamine content on $\mathrm{L}_{4}$ was about one-half of the value observed in di-oestrus, while in IUCD-containing horns the histamine content on $\mathrm{L}_{4}$ was the same as the di-oestrous value. These data are interpreted in terms of a chronic inflammatory response in the IUCD-containing horn.
\end{abstract}

The contraceptive action of a foreign body in the uterus is still only partially understood, but a number of changes are known to be brought about by an IUCD. The decidual cell reaction is inhibited in the rat uterine horn containing an IUCD (Doyle \& Margolis, 1964) and it has been suggested (Shelesnyak, 1966; Marcus, 1964) that this inhibition may be due to a depletion of the histamine available for stimulation of the decidual response. This paper presents measurements of histamine in control and IUCD-containing uterine horns of the rat.

Female rats of the Holtzmann strain were used. $\mathrm{L}_{0}$ designates the day spermatozoa were found in the vaginal smear. IUCDs, when present, consisted of about $1 \mathrm{~cm}$ of 3-0 surgical silk suture inserted with an atraumatic needle into one horn.

Uterine histamine was extracted by the method of Code \& McIntyre (1956) and assayed on the guinea-pig ileum. For each measurement on whole uterine horns, five to eight horns were transected at the utero-tubal and utero-cervical junctions and pooled. In addition, some measurements were made on pools of anti-mesometrial tissue, obtained by cutting eight to twelve whole horns longitudinally with scissors into approximately two halves and using only the half opposite the mesometrium. In every case, the measurements on IUCDcontaining horns were compared with the measurements on the control horns from the same animals.

The anti-histamine, diphenhydramine (Benadryl), at a concentration of $10^{-6} \mathrm{~g} / \mathrm{ml}$, completely abolished the contractile response to large doses of the uterine extract. The log dose-response curve was linear, and parallel lines were 
obtained with histamine and uterine extract. The average percentage of recovery in three trials was $91 \%$, and histamine measurements listed in the tables have been corrected for this recovery. A total of seven histamine measurements were made on di-oestrous control horns, giving an average and standard deviation of $2 \cdot 0 \pm 0.2 \mu \mathrm{g} / \mathrm{g}$, which agrees with the values reported for the same tissue by Spaziani \& Szego (1958) using the method of Code \& McIntyre (1956), and by Szego (1965) using the spectrofluorimetric method of Shore, Burkhalter \& Cohn (1959).

Table 1 lists the measured histamine concentrations in terms of wet tissue weight. In horns containing an IUCD, there was an increased concentration of histamine both in the whole horn and in anti-mesometrial tissue at both times measured. The increased histamine concentration occurred within the first $92 \mathrm{hr}$ after insertion of the device.

The interpretation of histamine concentration measurements in IUCDcontaining horns is complicated by the fact that the wet and dry weights of these horns are increased by the device (Parr \& Segal, 1966). The nature of the newly added tissue is unknown; it could be rich or poor in histamine. The difficulty in interpreting the data can be lessened by reporting both the concentration of histamine and the content of histamine per whole uterine horn (see Table 1).

The average weights of the control and IUCD-containing uterine horns used in each measurement are also listed. It can be seen in Table 1 that the content of histamine in IUCD-containing horns was considerably greater than in control horns in both di-oestrus and $\mathrm{L}_{4}$. The data also show that the histamine content of control horns on $\mathrm{L}_{4}$ was less than the di-oestrous value. In IUCD-containing horns, on the other hand, the histamine content on $\mathrm{L}_{4}$ was essentially the same as in di-oestrous horns. The decreased histamine concentration found in IUCD-containing horns at $\mathrm{L}_{4}$, when compared to the di-oestrous concentration, is thus due to a further weight increase during early gestation (Parr \& Segal, 1966) and not to a decrease in the amount of histamine present. In control horns, however, the decreased concentration of histamine on $\mathrm{L}_{4}$, compared to the di-oestrous concentration, reflects primarily a decreased content of histamine.

Studies from the laboratory of Shelesnyak $(1957,1959)$ have led to the suggestion that histamine may be the primary stimulus for the decidual reaction in rats. It has been further suggested that the inability of the IUCD-containing rat uterus to decidualize may be due to a deficiency of histamine, the proposed inducer, in the tissue. The greater than normal quantities of histamine found in the IUCD-containing uterine horn in the present studies do not support this suggestion. The concept of reduced availability of histamine as the primary explanation for the failure of the device-containing horn to decidualize is also inconsistent with the findings of Doyle \& Margolis (1964) who showed that the intraluminal injection into IUCD-containing horns of adequate doses of histamine failed to evoke a decidual response.

The increased histamine in IUCD-containing horns can be accounted for by the increased number of mast cells present in these horns (R. R. Chaudhury, personal communication). The additional mast cells are probably a part of the 


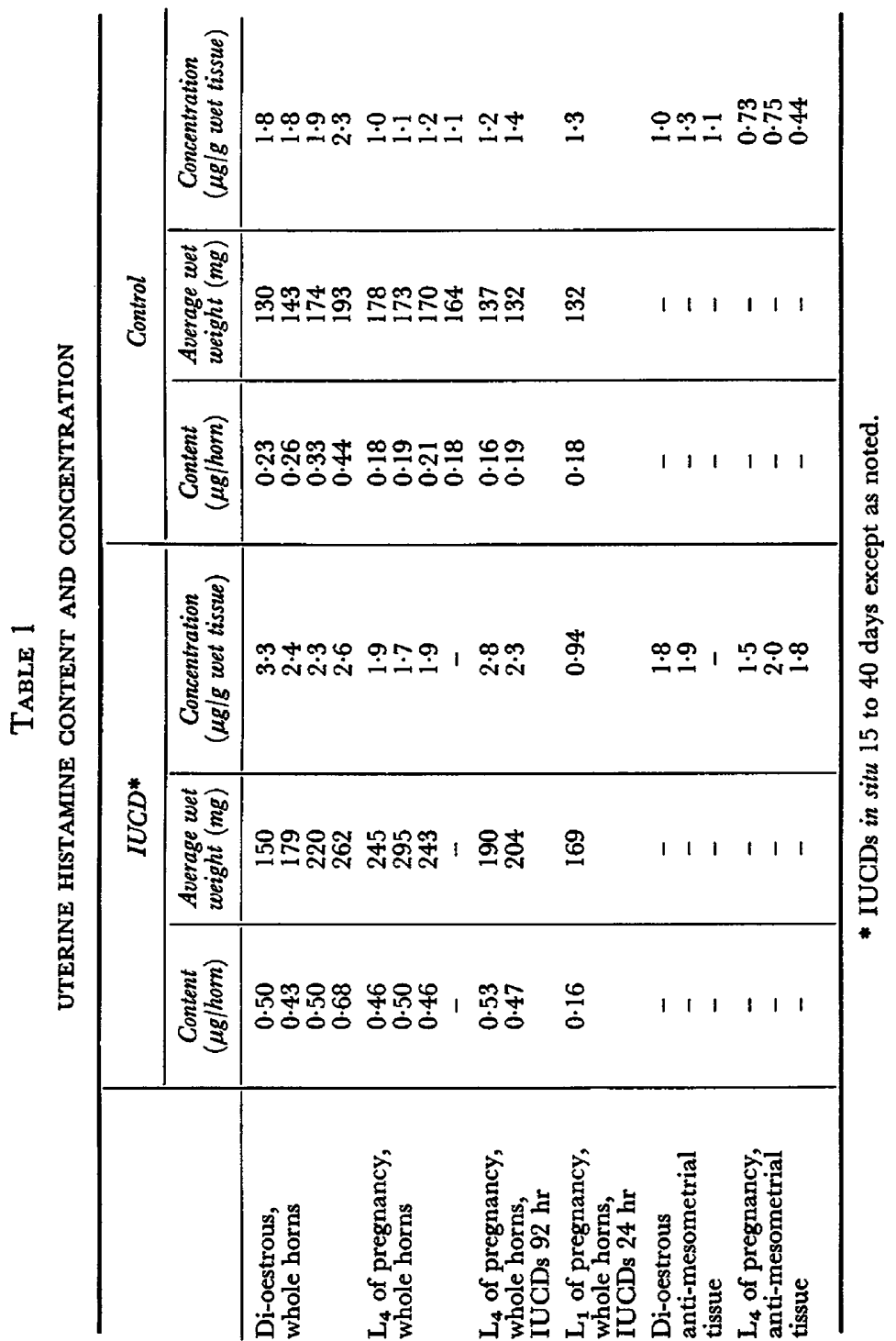


inflammation which has been observed in the device-containing horn (Greenwald, 1965), since some basophilic leucocytes are likely to be included in the leucocyte infiltration. This seems the most likely interpretation for the data presented here.

\section{REFERENCES}

CoDE, G. F. \& MCINTYre, F. C. (1956) Quantitative determination of histamine. Meth. biochem. Analysis, 3, 49.

Doyle, L. L. \& Margolis, A. J. (1964) Intrauterine foreign body. II. Inhibition of decidual reaction in the rat. Fert. Steril. 15, 607.

GREENWALD, G. S. (1965) Interruption of pregnancy in the rat by a uterine suture. F. Reprod. Fert. 9, 9.

Marcus, S. L. (1964) The effect of an IUD on the pH of the uterine fluid in the rat. Obstet. Gynec. 24, 878 .

PARR, E. L. \& SEgal, S. J. (1966) The effect of an intrauterine contraceptive device on the weight of the rat uterus. Fert. Steril. 17, 648.

Shelesnyax, M. C. (1957) Some experimental studies on the mechanism of ovum implantation in the rat. Recent Prog. Horm. Res. 13, 269.

Shelesnyak, M. C. (1959) Fall in uterine histamine associated with ovum implantation in pregnant rats. Proc. Soc. exp. Biol. Med. 100, 380.

Shelesnyak, M. G. (1966) Discussion. In Egg implantation, p. 26. Ed. G. E. W. Wolstenholme and M. O'Connor. Little Brown, Boston.

Shore, P. A., Burkhalter, A. \& Cohn, V. H., JR (1959) A method for the fluorometric assay of histamine in tissues. 7. Pharmac. exp. Ther. 127, 182.

Spaziani, E. \& Szego, C. M. (1958) The influence of estradiol and cortisol on uterine histamine of the ovariectomized rat. Endocrinology, 63, 669 .

Szego, C. M. (1965) The role of histamine in the mediation of hormone action. Fedn Proc. Fedn Am. Socs exp. Biol. 24, 1343. 